\title{
Use of oral fluids for efficient monitoring of influenza viruses in swine herds in Colombia
}

\author{
Uso de fluidos orales para el monitoreo eficiente de virus Influenza en granjas porcinas en Colombia
}

Uso de fluidos orais para monitoramento eficiente do vírus Influenza em rebanhos suínos na Colômbia

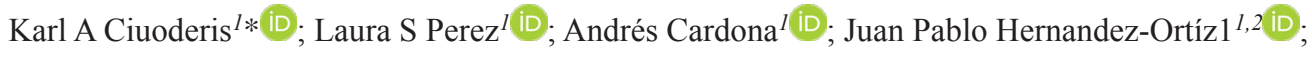 \\ Jorge E Osorio ${ }^{1,2}$ iD. \\ ${ }^{1}$ Colombia-Wisconsin One Health Consortium. Laboratorio One Health, Universidad Nacional de Colombia, Medellin, Colombia. \\ ${ }^{2}$ Department of materials, Universidad Nacional de Colombia, Medellin, Colombia. \\ ${ }^{3}$ Department of Pathobiological Sciences, School of Veterinary Medicine, University of Wisconsin, Madison, WI, USA.
}

\section{To cite this article:}

Ciuoderis KA, Perez LS, Cardona A, Hernandez-Ortiz JP, Osorio JE. Use of oral fluids for efficient monitoring of influenza viruses in swine herds in Colombia. Rev Colomb Cienc Pecu 2022; 35(3): 141-152. DOI: https://doi.org/10.17533/udea.rccp.v35n3a02

\begin{abstract}
Background: Influenza A virus (IAV) surveillance in swine is critical not only due to the direct impact of the disease in the pork industry but also because IAV are prone to interspecies transmission (from human to pigs and vice versa); therefore, its monitoring is fundamental from a public and animal health perspective. Several diagnostic techniques have been used to detect IAV infection from nasal samples in swine, while samples of oral fluids (OF) are in use as novel alternatives for pathogen detection. The OF allow for efficient and feasible low-cost disease detection at the herd level, with low risk of stress for the animals. Objective: To describe a surveillance strategy of IAV at the herd level during respiratory disease outbreaks in swine farms at tropical settings using porcine oral fluids. Methods: An active surveillance strategy was conducted in several farms with past records of respiratory disease. The IAV detection was conducted in five purposively selected swine farms from years 2014 to 2017. We investigated a total of 18 respiratory outbreaks of the disease. Swine OF were collected for IAV testing. An OF sample is described as a pen-based specimen collected from a group of $>20$ pigs per pen and/or per barn (stall-housed individually with close contact among them). The IAV infection was investigated in OF by rRT-PCR testing and confirmed by viral isolation in cell culture. Results: We found 107 (7.4\%) positives to IAV by rRT-PCR from a total of 1,444 OF samples tested. Additionally, 9 IAV isolates were all further identified as H1 subtype. Conclusions: Our results demonstrate that OF can be easily implemented as a novel, user-friendly, welfare-friendly, accurate and cost-effective sampling method for active surveillance and monitoring of IAV infections in swine farms in tropical settings.
\end{abstract}

Received: May 17, 2021; Accepted: October 5, 2021

*Corresponding author. Laboratorio Genómico One Health, Universidad Nacional de Colombia, bloque M15, Medellín, Colombia. E-mail:coord_cwohc@unal.edu.co 
Keywords: diagnostic techniques; disease detection; disease surveillance; epidemiological surveillance; infection; Influenza A virus; molecular; oral fluids; pig farm; RT-PCR; sampling; sampling techniques; swine.

\section{Resumen}

Antecedentes: La vigilancia del Virus Influenza A (IAV) en los cerdos es fundamental debido al impacto directo de la enfermedad en la industria porcina, pero también porque los IAV son propensos de transmisión entre especies (humanos a cerdos y viceversa), y por lo tanto su monitoreo es crítico desde las perspectivas de salud pública y animal. Actualmente existen varias técnicas de diagnóstico disponibles para detectar la infección por IAV a partir de muestras nasales en cerdos, sin embargo, se han implementado otras muestras como los fluidos orales (OF) como nuevas alternativas para la detección de patógenos. El OF permite una detección eficiente y factible de enfermedades a menor costo a nivel de rebaño, con menor riesgo de estrés para los animales. Objetivo: Describir una estrategia de vigilancia de IAV a nivel de hato por medio de fluidos orales porcinos durante brotes de enfermedades respiratorias en granjas porcinas en entornos tropicales. Métodos: Se llevó a cabo una estrategia de vigilancia activa en cinco granjas porcinas seleccionadas con antecedentes de enfermedades respiratorias. Se recolectaron OF porcinos para la prueba de IAV. Una muestra de OF se describió como una muestra grupal recolectada de un grupo de $>20$ cerdos por corral y/o por establo (si estaban alojados individualmente, pero tenían un contacto cercano entre ellos). La infección por IAV se investigó probando OF mediante rRT-PCR y la confirmación mediante aislamiento viral en cultivo celular. Resultados: La detección de IAV se llevó a cabo en cinco granjas seleccionadas intencionalmente entre 20142017. Investigamos un total de 18 eventos de brotes de enfermedades respiratorias. Del total de 1.444 OF muestras analizadas, encontramos $107(7,4 \%)$ positivos a IAV mediante rRT-PCR. Además, solo se obtuvieron 9 aislamientos de IAV y todos se identificaron además como subtipo H1. Conclusiones: Los resultados de nuestro estudio demostraron cómo la OF puede implementarse fácilmente como un método de muestreo novedoso, fácil de usar, amigable con el bienestar animal, preciso y rentable para la vigilancia activa y el monitoreo de infecciones por IAV en granjas porcinas en entornos tropicales.

Palabras clave: detección de enfermedades; fluidos orales; granja porcina; infección; molecular; monitoreo de enfermedades; muestreo; porcino; RT-PCR; técnica diagnóstica; vigilancia epidemiológica; virus de la Influenza A.

\section{Resumo}

Antecedentes: A vigilância do vírus Influenza A (IAV) em suínos é crítica devido ao impacto direto da doença na indústria de suínos, mas também porque os IAV são propensos a transmissão interespécies (de humanos para porcos e vice-versa) e, portanto, seu monitoramento é crítico do ponto de vista da saúde pública e animal. Atualmente, existem várias técnicas de diagnóstico disponíveis para detectar a infecção por IAV em amostras nasais de suínos, no entanto, outras amostras, como fluidos orais (OF), têm sido implementadas como novas alternativas para a detecção de patógenos. O OF permite uma detecção eficiente e viável de doenças com menor custo em nível de rebanho, com menor risco de estresse para os animais. Objetivo: Descrever uma estratégia de vigilância de IAV em nível de rebanho durante surtos de doenças respiratórias em granjas de suínos em ambientes tropicais por meio de fluidos orais suínos. Métodos: A estratégia de vigilância ativa foi conduzida em cinco granjas de suínos selecionadas com histórico de doenças respiratórias. Suínos OF foram coletados para teste de IAV. Uma amostra OF foi descrita como um espécime baseado em curral coletado de um grupo de $>20$ porcos por curral e/ou por celeiro (se eles foram alojados individualmente, mas tendo contato próximo entre eles). A infecção IAV foi investigada testando OF por rRT-PCR e confirmada por isolamento em cultura de células. Resultados: A detecção do IAV foi realizada em cinco fazendas selecionadas propositalmente entre 2014-2017. Nós investigamos um total de 18 eventos de surto de doença respiratória. Do total de 1.444 amostras de OF testadas, encontramos 107 (7,4\%) positivas para IAV por rRT-PCR. Além disso, apenas 9 isolados de IAV foram obtidos, e todos foram posteriormente identificados como subtipo H1. Conclusão: Os resultados de nosso estudo demonstraram como o OF pode ser facilmente implementado como um método de amostragem novo, amigável, amigável com o bem-estar, preciso e de baixo custo para vigilância ativa e monitoramento de infecções IAV em fazendas de suínos em ambientes tropicais.

Palavras-chave: amostragem; detecção de doenças; fluidos orais; fazenda de porcos; infecção; molecular; monitoreo de enfermidades; suíno; RT-PCR; técnica de diagnóstico; técnicas de amostragem; vigilância epidemiológica; vírus Influenza A. 


\section{Introduction}

Influenza A viruses (IAV) are an important cause of acute respiratory disease in animals and humans (Janke, 2013). Despite evidence of IAV reassortment in other species, swine are key intermediate hosts for the emergence of new viruses (Ma et al., 2009). Several studies have demonstrated transmission of IAV from humans to pigs (Adeola et al., 2010; Forgie et al., 2011), and from pigs to humans (Yassine et al., 2009). IAV transmission between the two species often result in emergence of new strains which spread between both populations ( $\mathrm{Xu}$ et al., 2011). This bidirectional transmission of IAV has heavily influenced the evolutionary history of IAV in both species. Sustained transmission and rapid adaptation of distinct human viruses after transmission to pigs adds more challenge to the already complicated global epidemiology of IAV in swine with implications in public health and swine health and production (Anderson et al., 2021). Thus, active surveillance of IAV in these populations should be closely monitored for global health concerns (Myers et al., 2007).

Swine IAV (SIAV) infections have significant impact on the affected herd (Cornelison et al., 2018), affecting pig performance, reducing feed conversion ratio, feed intake and weight gain (Olsen et al., 2002; Myers et al., 2007). Although sampling methods to detect SIAVinfected individuals in large populations require a high number of resources (Muñoz-Zanzi et al., 2000), aggregation of samples has been proposed as a cost-efficient tool for detecting diseases in these populations (Rotolo et al., 2018). The effectiveness of pathogen detection in pooled samples is highly dependent on the dilution effect (Arnold et al., 2009); however, several studies have demonstrated a no dilution effect when detecting SIAV in OF by molecular methods (Panyasing et al., 2016; Gerber et al., 2017).

Although SIAV surveillance have been extensively conducted worldwide, few studies have been reported in Colombia (Ramirez et al., 2012). Some potential limitations include technical and economic challenges when testing a significant number of individual samples from a herd (Corzo et al., 2013). However, SIAV monitoring in pigs could be facilitated using oral specimens which are efficient and effective for viral surveillance (Panyasing et al., 2016; Fablet et al., 2017). Therefore, we conducted a prospective observational study for SIAV surveillance at the herd level using porcine OF, providing proof of an efficient, simple, costeffective, animal welfare friendly and userfriendly sampling tool for IAV longitudinal monitoring in Colombian pig farms.

\section{Materials and Methods}

\section{Ethical considerations}

The study protocol was reviewed and approved by the institutional committee of the Colombian national swine producer's association (Porkcolombia) and by the Ethics Committee of Universidad de Antioquia, Medellín (Colombia; Act $\mathrm{N}^{\circ} 142$ ). Additionally, swine producers provided written consent to participate in the study before sample collection. All samples were collected by trained veterinarians. The study was conducted in compliance with local regulations and international guidelines for ethical conduct in the use of animals in research (https://www.apa.org/science/leadership/care/ guidelines).

\section{Study design}

A list of farms located in Antioquia province was obtained from Porkcolombia. Candidate sites (owners of these farms) were then contacted by phone to ask willingness to participate and to obtain informed consent for the study. This prospective observational study was conducted in five selected swine farms with past records of influenza-like illness.

The sample size per farm was estimated for disease detection from pooled samples in a large population using the Epitools epidemiology online calculator (Sergeant, 2014), with the following parameters: Aggregate sample size of $>20$ animals per sample, $80 \%$ test sensitivity at pool level (Romagosa et al., 2012), 95\% confidence, 
and $10 \%$. estimated disease prevalence. A sample of two OF per group was required to have a $90 \%$ probability to find at least $10 \%$ virus prevalence in the sampled subpopulation. An OF sample was described as a pen-based specimen or aggregate sample (Rotolo et al., 2018) collected from a group of $>20$ animals per pen and/or $>20$ animals per barn if they were housed individually with close contact among them, i.e., stall-housing in a breeding herd facility.

Sample collection was conducted upon request of the owners or farm technicians, once they suspected a respiratory disease outbreak was occurring in the farm. At the time of the visit, farm production units were inspected to record if there were groups of animals showing clinical signs of influenza-like illness (sneezing, coughing, nasal discharge, difficulty to breath, lethargy, and loss of appetite). Samples were taken from different pigs, including sows, nursery pigs, breeding, and finishing pigs regardless of whether they had clinical signs of respiratory illness or not. The OFs were collected from stall-housed or grouphoused pigs at each farm. Groups of animals were selected by simple random sampling using a random number method (Murato et al., 2020). In the stall-housed animals, a number was assigned to each individual and then the aggregate sample was collected hand-holding the rope individually rotating it in 20 randomly selected pigs within the barn. In the group-housed animals, a number was assigned to each pen within a barn and then the aggregate sample was collected holding the ropes at each randomly selected pen or group of animals. In both scenarios, it was guaranteed that resampling of animals did not occur. Samples were collected following the recommendations for the OF collection method previously described (HenaoDiaz et al., 2020; Rotolo, 2017). When the rope was saturated (30 to 60 of min. of chewing time) the fluid was extracted by manually squeezing inside a clean plastic bag. Thereafter, $2 \mathrm{ml}$ of sample was transferred into a tube containing $1 \mathrm{ml}$ of virus transport media (VTM), and transported at $4{ }^{\circ} \mathrm{C}$ to the laboratory within 8 hours. Samples were then processed or stored at $-80^{\circ} \mathrm{C}$ until use. VTM was composed of minimal essential medium with Earle's salts (MEM; MilliporeSigma, St.
Louis, MO, USA), 2x antibiotic-antimycotic solution [penicillin (300 IU/ml; MilliporeSigma, St. Louis, MO, USA), streptomycin (300 lg/ $\mathrm{ml}$; MilliporeSigma, St. Louis, MO, USA), gentamicin (150 lg/ml; MilliporeSigma, St. Louis, MO, USA), amphotericin B (0.75 lg/ml; Gibco, Grand Island, NY, USA)], in addition to gelatin (0.5\%; Amresco, Framingham, MA, USA) and bovine serum albumin $(0.5 \%$; MilliporeSigma, $\mathrm{St}$. Louis, MO, USA).

\section{rRT-PCR for IAV detection}

The RNA extraction from OF specimens was conducted by using a ZR viral kit (Zymo research, Irvine, CA, USA) following manufacturer's instructions. The rRT-PCR was performed in a 7500 fast thermocycler (Applied biosystems, Waltham, MA, USA) using TaqMan Fast Virus 1-Step Master Mix (Applied Biosystems) and specific primers/probe targeting a conserved region of IAV M gene (WHO, 2011). Positive (beta-propiolactone treated pandemic $\mathrm{H} 1 \mathrm{~N} 1$ virus) and negative controls were included in each run. Running conditions: 1 cycle at $50^{\circ} \mathrm{C}$ for $5 \mathrm{~min}, 1$ cycle at $95^{\circ} \mathrm{C}$ for $20 \mathrm{~s}$ and 40 cycles of $95^{\circ} \mathrm{C}$ for 15 $\mathrm{s}, 60^{\circ} \mathrm{C}$ for $60 \mathrm{~s}$. Analysis of amplification curves was conducted by using thermal cycler system software. The baseline was set automatically and cycle threshold was visually set to halfway of the exponential phase of the positive control. Samples with a fluorescence cycle threshold value $<39$ were considered positive.

The RT-PCR assay efficiency and analytical sensitivity (limit of detection) were determined for viral detection from OF samples. Virus spiked OF samples were used to investigate interfering factors in the assay efficiency. Briefly, five OF samples from healthy pigs were tested by adding $50 \mathrm{uL}$ of beta-propiolactone treated pandemic $\mathrm{H} 1 \mathrm{~N} 1$ virus stock $(1 \times 106$ TCID 50/ml). Samples were tested in two independent replicates by performing 10-fold serial dilutions. Assay efficiency was calculated by Linear regression analysis of the serial 10 -fold dilutions using the following formula: $(\mathrm{E})=[10(1$ / slope) ] - 1 (Stordeur et al., 2002). The limit of detection for the assay was defined as the highest dilution at which all replicates were positive. 


\section{Virus isolation}

The rRT-PCR IAV positive OF samples were selected for virus isolation. Briefly, confluent monolayers of MDCK cells were prepared in 24well plates $\left(\right.$ Costar $^{\circledR}$, Corning, NY, USA). Cell culture media was removed and monolayers were washed three times with 1X PBS solution (Gibco, Grand Island, NY, USA). Prior to inoculation, sample was filtered using 0.45 um syringe filter (Millipore, Billerica, MA, USA). Viral inoculum was prepared using 300 ul of sample filtrate diluted in $700 \mathrm{ul}$ of infection media (Decorte et al., 2015). Each sample was inoculated into 2 wells $(\sim 0.5 \mathrm{ml} /$ well $)$ and then incubated at $37^{\circ} \mathrm{C}$ with $5 \% \mathrm{CO} 2$ for up to $72 \mathrm{~h}$. Cell cultures were daily observed for cytopathic effects (CPE). If CPE was present, cell culture supernatant was subjected to hemagglutination assay (HA). HA was performed following methods previously described (Killian, 2014). HA-positive cultures were further tested by rRT-PCR for IAV. Cells not showing CPE were exposed to a freeze-thaw cycle $\left(-80\right.$ and $\left.37^{\circ} \mathrm{C}\right)$ and then tested by HA. Cultures negative for HA were subjected to two additional passages by re-inoculating into fresh confluent MDCK cells. If $\mathrm{CPE}$ and HA were negative at $72 \mathrm{~h}$ after the third passage samples were considered negative for IAV isolation. Isolates obtained were partially sequenced by sanger sequencing service at an external facility (Macrogen, Korea) and identified using the BLAST tool for Hemaglutinin viral gene (Van den Hoecke et al., 2015).

\section{Statistical analysis}

Data were tabulated and classified as positive or negative based on a 39-cycle threshold (ct) cutoff point. A swine group was classified as IAV positive if at least one pen-based OF sample tested positive by rRT-PCR. Descriptive statistics were obtained for each variable according to their data type. Comparison of infection status between groups was tested by Chi squared test. All analyses were performed using the R studio software v3.5.0 (RStudio Team, 2016).

\section{Results}

\section{Monitored farms}

A list of 21 candidate farms was obtained from the national pork producers association. From these, 10 swine producers accepted to participate in the study and five of them were selected for IAV monitoring. These farms were located in the Province of Antioquia (municipalities of Yolombo, Támesis, Betulia, Caldas, and Barbosa; Figure 1). Molecular detection of IAV was carried out in porcine OF collected from January 2014 to December 2017. The farms were farrow to finishing, with common biosecurity practices (disinfection of facilities, quarantine periods for entering personnel and animals, shower and changing clothes at entry, boots disinfection at barn or pen entry). The size of the breeding herd per farm varied from 100 to 500 female pigs. Replacement gilts were obtained from the same farm, except for two farms that had external reposition. Some of the farms had documented serology testing for SIAV but none had records for virus detection by molecular methods. None of the farms vaccinated against SIAV. Environmental conditions, altitude and climate varied from farm to farm; however, these factors were not considered in the analysis.

\section{IAV detection and viral isolation}

Five swine farms were monitored for IAV detection. Overall, from the total $(n=1,444)$ OF samples tested, $107 \quad(7.4 \%)$ samples were positive to IAV by rRT-PCR (Table 1). Furthermore, Farm I was monitored two times (August 2015 and March 2016) detecting 11 samples positive $(12.9 \% ; \mathrm{n}=85)$ to IAV by rRT-PCR. Farm II was monitored three times (October 2015, March and April 2016) detecting -in total- 14 samples positive $(11.3 \%$; $n=124)$ to IAV by rRT-PCR. Farm III was monitored 10 times (October and December 2015, February to September 2016, and February 2017) detecting 36 samples positive $(5.3 \% ; n=674)$ to IAV by rRT-PCR. Farm IV was monitored three times (January and August 2014, and February 2015) 
detecting 4 samples positive $(7.1 \% ; n=56)$ to IAV by rRT-PCR. Farm V was monitored eleven times (from February 2016 to February 2017) detecting 42 samples positive $(8.3 \%$; $n=505)$ to IAV by rRT-PCR. We investigated a total of 29 outbreaks of respiratory disease suspected of IAV infection.

We confirmed IAV infection in groups of pigs with and without clinical signs of respiratory disease. The IAV positive samples were found in a wide range of pigs including sows, breeding herds, nursery and finishing pigs at each farm (Table 1). Nine viral isolates were successfully obtained from IAV rRT-PCR positive OF samples after cell culture isolation on MDCK cells. At least one IAV isolate was obtained per farm. Active infection and circulation of IAV was confirmed in all the farms monitored.

No inhibition factors for the rRT-PCR test were present in the specimen (porcine oral fluid) after investigation using spiked OF samples. Good performance of the testing method was found with a limit of detection of 105.5 TCID50/ml observed and a test efficiency greater than $99 \%$.

\section{Discussion}

This prospective study provided important information about using OF samples for the detection of IAV in swine herds as an efficient method for disease surveillance and monitoring. This is the first study describing the use of aggregate samples as a screening method to monitor IAV in swine farms over time in Colombia. Our results show how to overcome the common diagnostic challenges under field conditions in swine farms where the testing of a number of individual pigs is limited, the number of pigs per pen differs, and the true prevalence of IAV within a pen is unknown. Therefore, we conclude that monitoring and detection of SIAV from OF pen-based samples in swine herds was successful under the conditions of our study.

Routine surveillance of swine diseases has become more important in recent years as a part of health programs and has increased attention after the impact seen from pandemic diseases; however, collecting appropriate numbers of individual samples can be stressful for the pigs, costly, and labor-intensive (Gerber et al., 2017).
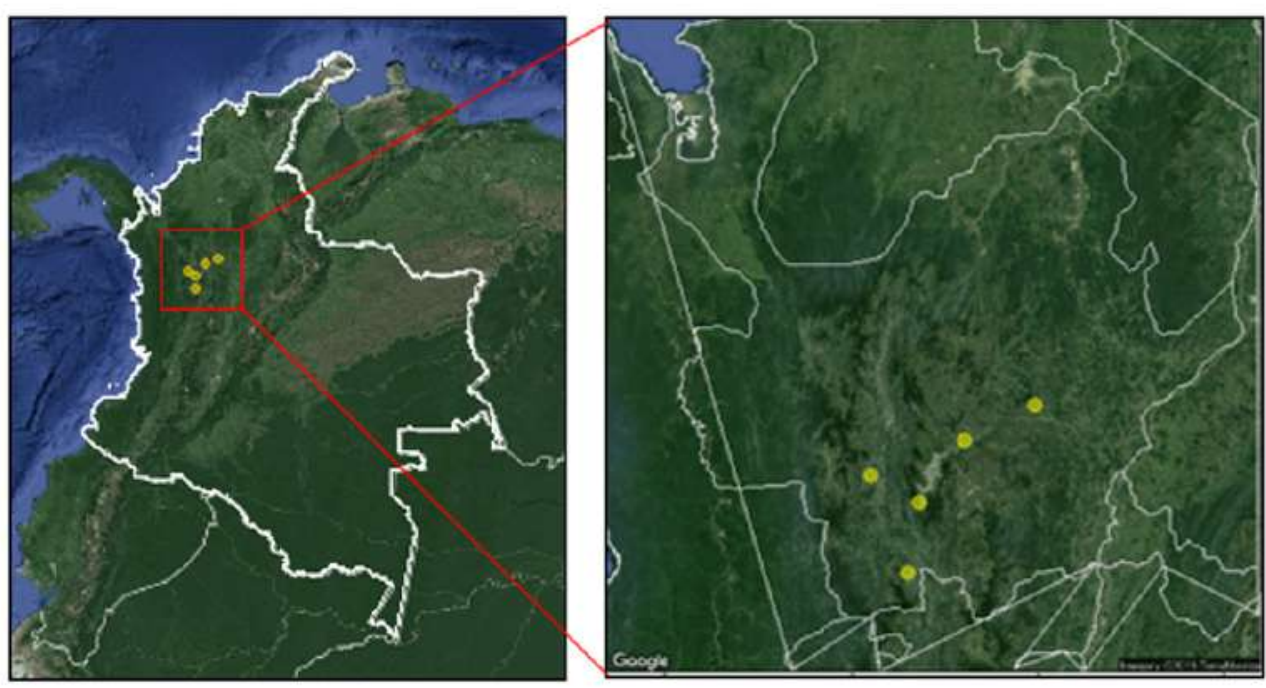

Figure 1. Location of the study sites (pig farms) in Colombia (left), Antioquia province (right). 
Table 1. Summary of sample collection and IAV rRT-PCR testing results of oral fluids obtained in five monitored pigs farms located in Antioquia province, Colombia (years 2014 to 2017).

\begin{tabular}{|c|c|c|c|}
\hline Subjects & Positive & Total & $\%$ \\
\hline 2014 & 4 & 36 & 11.1 \\
\hline Farm IV & 4 & 36 & 11.1 \\
\hline Breeding sows (gestating-farrowing) & 1 & 7 & 14.3 \\
\hline Gilts & 2 & 17 & 11.8 \\
\hline Nursery & 1 & 12 & 8.3 \\
\hline 2015 & 25 & 177 & 14.1 \\
\hline Farm I & 9 & 46 & 19.6 \\
\hline Growing-finishing & 5 & 28 & 17.9 \\
\hline Nursery & 4 & 18 & 22.2 \\
\hline Farm II & 9 & 26 & 34.6 \\
\hline Breeding sows (gestating-farrowing) & 3 & 17 & 17.6 \\
\hline Nursery & 6 & 9 & 66.7 \\
\hline Farm III & 9 & 85 & 10.6 \\
\hline Breeding sows (gestating-farrowing) & 0 & 16 & 0.0 \\
\hline Growing-finishing & 1 & 13 & 7.7 \\
\hline Nursery & 8 & 56 & 14.3 \\
\hline Farm IV & 0 & 20 & 0.0 \\
\hline Breeding sows (gestating-farrowing) & 0 & 8 & 0.0 \\
\hline Growing-finishing & 0 & 8 & 0.0 \\
\hline Nursery & 0 & 4 & 0.0 \\
\hline 2016 & 71 & 1,069 & 6.6 \\
\hline Farm I & 2 & 39 & 5.1 \\
\hline Breeding sows (gestating-farrowing) & 0 & 8 & 0.0 \\
\hline Growing-finishing & 1 & 26 & 3.8 \\
\hline Nursery & 1 & 5 & 20.0 \\
\hline Farm II & 5 & 98 & 5.1 \\
\hline Breeding sows (gestating-farrowing) & 0 & 64 & 0.0 \\
\hline Growing-finishing & 0 & 15 & 0.0 \\
\hline Nursery & 5 & 19 & 26.3 \\
\hline Farm III & 27 & 527 & 5.1 \\
\hline Breeding sows (gestating-farrowing) & 2 & 165 & 1.2 \\
\hline Gilts & 0 & 27 & 0.0 \\
\hline Growing-finishing & 6 & 240 & 2.5 \\
\hline Nursery & 19 & 95 & 20.0 \\
\hline Farm V & 37 & 405 & 9.1 \\
\hline Breeding sows (gestating-farrowing) & 2 & 82 & 2.4 \\
\hline Gilts & 24 & 193 & 12.4 \\
\hline Growing-finishing & 0 & 32 & 0.0 \\
\hline Nursery & 11 & 98 & 11.2 \\
\hline 2017 & 5 & 162 & 3.1 \\
\hline Farm III & 0 & 62 & 0.0 \\
\hline Nursery & 0 & 62 & 0.0 \\
\hline Farm V & 5 & 100 & 5.0 \\
\hline Nursery & 5 & 100 & 5.0 \\
\hline Total & 107 & 1444 & 7.4 \\
\hline
\end{tabular}


Additionally, individual surveillance and molecular testing of large number of individual samples become a challenge for swine producers. The OF sampling method overcomes this limitation, allowing aggregate sample testing, greatly reducing costs, and giving valuable information at a herd level.

Aggregate OF samples can also be collected in the field by trained personnel, demonstrating the easiness of this sampling method. Thus, OF requires minimal training and allows testing large sample numbers providing a non-invasive and useful approach for active surveillance in swine populations in a cost-effectively manner (Panyasing et al., 2016). Our study demonstrates how IAV can be efficiently monitored in swine herds using $\mathrm{OF}$ as a screening method. The application of this approach in swine productions in tropical settings can facilitate the detection and monitoring of pathogens of interest for animal and public health.

Virus isolation from samples such as OF becomes challenging sometimes. Several factors contribute to it. Among others, virus inactivation may occur by naturally occurring enzymes or other components present in the OF. Salivary proteins and other components in saliva can significantly inhibit influenza viruses in humans (White et al., 2009). Such components have not been examined in porcine saliva, but experiments have shown inhibitory activity of OF against H1N1 virus (Hartshorn et al., 2006). However, IAV have been isolated in experimentally spiked swine OF (Decorte et al., 2015), which suggests that the components in these specimens do not completely inhibit infectivity and viral growth, and it was confirmed in our study with the successful virus isolation. On the other hand, sensitivity of molecular detection of IAV has been described as higher for OF samples than others sample types (Henao-Diaz et al., 2020).

Interestingly in our study, most pig groups found infected with IAV did not show respiratory disease signs of infection. Therefore, if an infected pig does not show clinical signs of disease it makes it difficult to select and collect appropriate individual samples for disease testing (Grøntvedt et al., 2011; Buehler et al., 2014), highlighting how critical it is to implement detection strategies at the herd level. The results of our study show that OF can be used for IAV detection in swine herds as a routine method with or without clinical signs of respiratory disease. In addition, these specimens can be a good source for testing other pathogens and other laboratory methods such as viral isolation and subsequent subtyping and sequencing of the virus. The applicability of sampling based on OF for surveillance of infections in pig populations have becoming more frequent and well accepted as a valuable tool for detection of many other important swine pathogens ( Trang et al., 2014; Hernández-García et al., 2017; Atkinson et al., 2019; Barrera-Zarate et al., 2019; Henao-Diaz et al., 2020).

The findings of our study provide valuable information regarding the use of $\mathrm{OF}$ for molecular detection of IAV in swine farms in one of the main pork producing regions of Colombia. The OF were used to demonstrate the application of an aggregate sampling method as a routine, efficient and cost-effective tool for active surveillance of respiratory viral diseases. Our results also suggested that IAV might represent a common cause of respiratory disease in swine farms. Therefore, routine use of groupbased sampling with OF facilitates pathogen detection at the herd level and contributes as an efficient strategy to monitor viral swine diseases of great importance for the pig industry.

\section{Declarations}

\section{Funding}

This project was supported by the Center of Excellence for Influenza Research and Surveillance, the Porkcolombia-Fondo Nacional Para la Porcicultura Association, and by the University of Wisconsin-Madison/Consortium Colombia-Wisconsin One Health. This project was also partially funded by the General Royalty System - Colciencias, Colombia, grant 785-2017. 


\section{Conflicts of interest}

The authors declare they have no conflicts of interest with regard to the work presented in this report.

\section{Author contributions}

KAC: Writing - original draft, data curation, formal analysis, writing - review and editing. LSP: writing - review \& editing, laboratory analysis. AC: writing - review \& editing, laboratory analysis. JPO: writing - review and editing. JPHO: writing - review \& editing.

\section{References}

Adeola O, Adeniji J, Olugasa B. Detection of haemagglutination-inhibiting antibodies against human $\mathrm{H} 1$ and $\mathrm{H} 3$ strains of Influenza A viruses in pigs in Ibadan, Nigeria. Zoonoses Public Health 2010; 57(7-8): e89-e94. https://doi.org/10.1111/j.1863-2378.2009.01268.x

Anderson TK, Chang J, Arendsee ZW, Venkatesh D, Souza CK, Kimble JB, Lewis NS, Davis CT, Vincent AL. Swine Influenza A viruses and the tangled relationship with humans. Cold Spring Harb Perspect Med 2021; 11(3): a038737. https://doi.org/10.1101/cshperspect.a038737

Arnold M, Mueller-Doblies D, Carrique-Mas J, Davies R. The estimation of pooled-sample sensitivity for detection of Salmonella in turkey flocks. J Appl Microbiol 2009; 107(3): 936-943. https://doi.org/10.1111/j.1365-2672.2009.04273.x

Atkinson B, Bearson B, Loving C, Zimmerman J, Kich J, Bearson S. Detection of Salmonella-specific antibody in swine oral fluids. Porc Heal Manag 2019; 5(29): 1-5. https://doi.org/10.1186/s40813-019-0136-7

Barrera-Zarate J, Andrade M, Pereira C, Vasconcellos A, Wagatsuma M, Sato J, Daniel A, Rezende LA, Otoni L, Laub R, Macedo N, Costa C, Haddad J, Guedes R. Oral fluid for detection of exposure to Lawsonia intracellularis in naturally infected pigs. Vet J 2019; 244: 34-36. https://doi.org/10.1016/j.tvj1.2018.12.003
Brown E. Influenza virus genetics. Biomed Pharmacother 2000; 54(4): 196-209. https://doi.org/10.1016/S0753-3322(00)89026-5

Buehler J, Lager K, Vincent A, Miller C, Thacker E, Janke B. Issues encountered in development of enzyme-linked immunosorbent assay for use in detecting Influenza A virus subtype H5N1 exposure in swine. J Vet Diagnostic Investig 2014; 26(2): 277-281. https://doi.org/10.1177/1040638713518775

Cameron A, Gardner I, Doherr M, Wagner B. Sampling considerations in surveys and monitoring and surveillance systems: methods and applications. In: Salman M, editor. Animal disease surveillance and survey systems. Iowa: Iowa State Press; 2008. p. 47-66. https://doi.org/10.1002/9780470344866.ch4

Cornelison A, Karriker L, Williams N, Haberl B, Stalder K, Schulz L, Patience J. Impact of health challenges on pig growth performance, carcass characteristics, and net returns under commercial conditions. Transl Anim Sci 2018; 2(1): 50-61. https://doi.org/10.1093/tas/txx005

Cortey M, Napp S, Alba A, Pileri E, Grau-Roma L, Sibila M, Segalés J. Theoretical and experimental approaches to estimate the usefulness of pooled serum samples for the diagnosis of postweaning multisystemic wasting syndrome. J Vet Diagnostic Investig 2011; 23(2): 233-240. https://doi. org/10.1177/104063871102300206

Corzo C, Culhane M, Juleen K, StiggerRosser E, Ducatez M, Webby R, Lowe J. Active surveillance for influenza a virus among swine, midwestern United States, 2009-2011. Emerg Infect Dis 2013; 19(6): 954-960. https://doi.org/10.3201/eid1906.121637

Decorte I, Steensels M, Lambrecht B, Cay A, De Regge N. Detection and isolation of swine influenza A virus in spiked oral fluid and samples from individually housed, experimentally infected pigs: potential role of porcine oral fluid in active influenza A virus surveillance in swine. PLoS One 2015; 10(10): e0139586. https://doi.org/10.1371/journal.pone.0139586 
Fablet C, Rose N, Bernard C, Messager I, Piel Y, Grasland B. Estimation of the diagnostic performance of two ELISAs to detect PCV2 antibodies in pig sera using a Bayesian method. J Virol Methods 2017; 249: 121-125. https://doi.org/10.1016/j.jviromet.2017.09.002

Forgie S, Keenliside J, Wilkinson C, Webby R, Lu P, Sorensen O, Fonseca K, Barman S, Rubrum A, Stigger E, Marrie T, Marshall F, Spady D, Hu J, Loeb M, Russell M, Babiuk L. Swine outbreak of pandemic influenza A virus on a Canadian research farm supports human-to-swine transmission. Clin Infect Dis 2011; 52(1):10-18. https://doi.org/10.1093/cid/ciq030

Gerber P, Dawson L, Strugnell B, Burgess R, Brown $\mathrm{H}$, Opriessnig T. Using oral fluids samples for indirect influenza A virus surveillance in farmed UK pigs. Vet Med Sci 2017; 3(1):3-12. https://doi.org/10.1002/vms3.51

Grøntvedt C, Er C, Gjerset B, Germundsson A, Framstad T, Brun E, Jørgensen A, Lium B. Clinical impact of infection with pandemic influenza (H1N1) 2009 virus in naïve nucleus and multiplier pig herds in Norway. Influenza Res Treat 2011; 2011:1-6. https://doi.org/10.1155/2011/163745

Hartshorn K, Ligtenberg A, White M, Eijk M, Hartshorn M, Pemberton L, Holmskov U, Crouch E. Salivary agglutinin and lung scavenger receptor cysteine-rich glycoprotein 340 have broad antiinfluenza activities and interactions with surfactant protein $\mathrm{D}$ that vary according to donor source and sialylation. Biochem J 2006; 393(2):545-553. https://doi.org/10.1042/BJ20050695

Henao-Díaz A, Giménez-Lirola L, Baum D, Zimmerman J. Guidelines for oral fluidbased surveillance of viral pathogens in swine. Porc Heal Manag 2020; 6(28):1-12. https://doi.org/10.1186/s40813-020-00168-w

Hernández-García J, Robben N, Magnée $\mathrm{D}$, Eley T, Dennis I, Kayes S, Thomson J, Tucker A. The use of oral fluids to monitor key pathogens in porcine respiratory disease complex. Porc Heal Manag 2017; 3(7):1-13. https://doi.org/10.1186/s40813-017-0055-4
Janke B. Clinicopathological features of swine influenza. Curr Top Microbiol Immunol 2013;370: 69-83. https://doi.org/10.1007/82 2013 308

Janke B. Diagnosis of viral respiratory disease in swine. Swine Heal Prod 1995; 3:116-120. Available in: https://www.aasv.org/shap/issues/ v3n3/v3n3p116.pdf

Killian M. Hemagglutination assay for influenza virus. In: Spackman E, editor. Animal influenza virus. Methods in molecular biology (methods and protocols). New York:HumanaPress;2014.p. 3-9. https://doi.org/10.1007/978-1-4939-0758-8_ 1

Ma W, Lager K, Vincent A, Janke B, Gramer M, Richt J. The role of swine in the generation of novel influenza viruses. Zoonoses Public Health 2009; 56(6-7): 326-337. https://doi.org/10.1111/ j.1863-2378.2008.01217.x

Muñoz-Zanzi C, Thurmond M, Hietala S, Johnson W. Factors affecting sensitivity and specificity of pooled-sample testing for diagnosis of low prevalence infections. Prev Vet Med 2006; 74(4): 309-322. https://doi.org/10.1016/j.prevetmed.2005.12.006

Murato Y, Hayama Y, Shimizu Y, Sawai $\mathrm{K}$, Yamamoto T. Evaluation of sampling methods for effective detection of infected pig farms during a disease outbreak. PLoS ONE 2020; 15(10): e0241177. https://doi.org/10.1371/journal.pone.0241177

Myers K, Olsen C, Gray G. Cases of swine influenza in humans: A review of the literature. Clin Infect Dis 2007; 44(8): 1084-1088. https://doi.org/10.1086/512813

Olsen C, Brammer L, Easterday B, Arden N, Belay E, Baker I, Cox N. Serologic evidence of $\mathrm{H} 1$ swine influenza virus infection in swine farm residents and employees. Emerg Infect Dis 2002; 8(8):814-819. https://doi.org/10.3201/eid0808.010474 
Olsen C, Carey S, Hinshaw L, Karasin A. Virologic and serologic surveillance for human, swine and avian influenza virus infections among pigs in the north-central United States. Arch Virol 2000; 145:1399-1419. https://doi.org/10.1007/s007050070098

Olsen, C.W., Karasin, A.I., Carman, S., Li, Y., Bastien, N., Ojkic, D., Alves, D., Charbonneau, G., Henning B, Low D, Burton L, Broukhanski G. Triple Reassortant H3N2 Influenza A, Canada, 2005. Emerg Infect Dis 2006; 12(7):1132-1135. https://doi.org/10.3201/eid1207.060268

Panyasing Y, Goodell C, Kittawornrat A, Wang C, Levis I, Desfresne L, Rauh R, Gauger P, Zhang $\mathrm{J}$, Lin X, Azeem S, Ghorbani-Nezami S, Yoon $\mathrm{K}$, Zimmerman J. Influenza A virus surveillance based on pre-weaning piglet oral fluid samples. Transbound Emerg Dis 2016; 63(5): e328-e338. https://doi.org/10.1111/tbed.12307

Ramírez A, Wang C, Prickett J, Pogranichniy R, Yoon K, Main R, Johnson J, Rademacher C, Hoogland M, Hoffmann P, Kurtz A, Kurtz E, Zimmerman J. Efficient surveillance of pig populations using oral fluids. Prev Vet Med 2012; 104(3-4): 292-300. https://doi.org/10.1016/j.prevetmed.2011.11.008

Romagosa A, Gramer M, Joo H, Torremorell M. Sensitivity of oral fluids for detecting influenza A virus in populations of vaccinated and non-vaccinated pigs. Influenza Other Respi Viruses 2012; 6(2):110-118. https://doi.org/10.1111/j.1750-2659.2011.00276.x

Rotolo M, Sun Y, Wang C, Giménez-Lirola L, Baum D, Gauger P, Harmon K, Hoogland M, Main R, Zimmerman J. Sampling guidelines for oral fluid-based surveys of group-housed animals. Vet Microbiol 2017; 209: 20-29. https://doi.org/10.1016/j.vetmic.2017.02.004

Rotolo ML, Main RG, Zimmerman JJ. Herd-level infectious disease surveillance of livestock populations using aggregate samples. Anim Health Res Rev 2018; 19(1):53-64. https://doi.org/10.1017/S1466252318000038
Rovira A, Cano J, Muñoz-Zanzi C. Feasibility of pooled-sample testing for the detection of porcine reproductive and respiratory syndrome virus antibodies on serum samples by ELISA. Vet Microbiol 2008; 130(1-2): 60-68. https://doi.org/10.1016/j.vetmic.2007.12.016

Sandbulte M, Spickler A, Zaabel P, Roth J. Optimal use of vaccines for control of Influenza A virus in swine. Vaccines 2015; 3(1): 22-73. https://doi.org/10.3390/vaccines3010022

Sergeant E. Epitools epidemiological calculators. 2014. URL: https://epitools.ausvet.com.au/

Stordeur P, Poulin L, Craciun L, Zhou L, SchandenéL, DeLavareilleA, Goriely S, Goldman M. Cytokine mRNA quantification by real-time PCR. J Immunol Methods 2002; 259(1-2): 55-64. https://doi.org/10.1016/S0022-1759(01)00489-6

RStudio Team. RStudio: Integrated Development for R. RStudio, Inc. 2016. URL: http://www. rstudio.com/

Trang N, Hirai T, Yamamoto T, Matsuda M, Okumura N, Giang N, Lan N, Yamaguchi R. Detection of porcine reproductive and respiratory syndrome virus in oral fluid from naturally infected pigs in a breeding herd. J Vet Sci 2014; 15(3): 361-367. https://doi.org/10.4142/jvs.2014.15.3.361

Van den Hoecke S, Verhelst J, Vuylsteke M, Saelens X. Analysis of the genetic diversity of influenza A viruses using next-generation DNA sequencing. BMC Genomics 2015; 16:79. https://doi.org/10.1186/s12864-015-1284-z

Vincent A, Perez D, Rajao D, Anderson T, Abente $\mathrm{E}$, Walia $\mathrm{R}$, Lewis N. Influenza A virus vaccines for swine. Vet Microbiol 2017; 206:35-44. https://doi.org/10.1016/j.vetmic.2016.11.026

White M, Helmerhorst E, Ligtenberg A, Karpel M, Tecle T, Siqueira W, Oppenheim F, Hartshorn K. Multiple components contribute to ability of saliva to inhibit influenza viruses. Oral Microbiol Immunol 2009; 24(1):18-24. https://doi.org/10.1111/j.1399-302X.2008.00468.x 
WHO-World Health Organization. WHO information for molecular diagnosis of influenza virus in humans - update. 2011; [access date: Jan 2012] URL: https://www.who.int/influenza/ gisrs laboratory/molecular_diagnosis/en/

Xu M, Huang Y, Chen J, Huang Z, Zhang J, Zhu Y, Xie S, Chen Q, Wei W, Yang D, Huang X, Xuan H, Xiang H. Isolation and genetic analysis of a novel triple-reassortant $\mathrm{H} 1 \mathrm{~N} 1$ influenza virus from a pig in China. Vet Microbiol 2011; 147(3-4): 403-409. https://doi.org/10.1016/j.vetmic.2010.07.012

Yassine H, Khatri M, Zhang Y, Lee C, Byrum B, O'QuinJ, SmithK, SaifY.Characterization oftriple reassortant $\mathrm{H} 1 \mathrm{~N} 1$ influenza $\mathrm{A}$ viruses from swine in Ohio. Vet Microbiol 2009; 139(1-2):132-139. https://doi.org/10.1016/j.vetmic.2009.04.028 